\title{
HIV-1 tuberculosis-associated immune reconstitution inflammatory syndrome
}

\author{
Rachel P. J. Lai ${ }^{1}$ • Graeme Meintjes ${ }^{2,3,4}$ • Robert J. Wilkinson ${ }^{1,2,3,4}$
}

Received: 1 July 2015 / Accepted: 21 September 2015 / Published online: 30 September 2015

(C) The Author(s) 2015. This article is published with open access at Springerlink.com

\begin{abstract}
Patients co-infected with HIV-1 and tuberculosis (TB) are at risk of developing TB-associated immune reconstitution inflammatory syndrome (TB-IRIS) following commencement of antiretroviral therapy (ART). TB-IRIS is characterized by transient but severe localized or systemic inflammatory reactions against Mycobacterium tuberculosis antigens. Here, we review the risk factors and clinical management of TB-IRIS, as well as the roles played by different aspects of the immune response in contributing to TB-IRIS pathogenesis.
\end{abstract}

Keywords HIV-1 infection · Tuberculosis · Immune reconstitution inflammatory syndrome $\cdot$ Drug therapy-complications

\section{HIV-tuberculosis co-infection}

Human immunodeficiency virus type 1 (HIV-1) and Mycobacterium tuberculosis are two major infectious diseases and

This article is a contribution to the Special Issue on Immunopathology of Mycobacterial Diseases - Guest Editor: Stefan Kaufmann

Robert J. Wilkinson

Robert.Wilkinson@uct.ac.za

1 The Francis Crick Institute, Mill Hill Laboratory, London NW7 1AA, UK

2 Institute of Infectious Disease and Molecular Medicine, Faculty of Health Sciences, University of Cape Town, Room 3.03.05, Wolfson Pavilion, Anzio Road, Observatory, Cape Town 7925, South Africa

3 Department of Medicine, Imperial College London, London W2 1PG, UK

4 Department of Medicine, University of Cape Town, Observatory, Cape Town 7925, South Africa each was responsible for causing approximately 1.5 million deaths in 2013 [1, 2]. There were an estimated 9.0 million cases of active tuberculosis (TB) in 2013, among which about 1.1 million (13\%) were HIV-1 co-infected [2]. The prevalence of HIV-1 co-infection among TB cases is the highest in Africa, accounting for around $78 \%$ of the total HIV-TB cases.

HIV-1 infection and active TB disease individually lead to severe immune impairment and they can also exacerbate the disease progression and pathology of one another. Tuberculosis can cause lymphocytopenia in the absence of HIV-1 or other cause of immunodeficiency [3,4]. When $\mathrm{CD}^{+} \mathrm{T}$ cells counts were controlled for, HIV-1 patients with active TB disease still have more a rapid course of disease progression and poorer survival rate than those without active TB [5]. Furthermore, people living with HIV-1 are 26-31 times more likely to develop TB than HIV-uninfected individuals [6].

HIV-1 causes functional disruption of the immune response and impairs the host's ability to control $M$. tuberculosis infection via several mechanisms (reviewed in [7]). Firstly, HIV-1 replication is higher in stimulated macrophages at the site of M. tuberculosis infection [8,9], and higher viral loads in bronchoalveolar lavage and in pleural fluid have been observed $[10,11]$. Secondly, HIV-1-infected macrophages have reduced secretion of TNF- $\alpha$ that associates with reduced apoptosis in response to $M$. tuberculosis $[12,13]$. While expression of TLR2 and TLR4 are preserved in HIV-1-infected macrophages, TNF- $\alpha$ secretion in response to specific TLR agonists, as well as signal transduction through IRAK-1 and NF-KB nuclear translocation, are significantly reduced [13]. Finally, HIV-1 infects and depletes $\mathrm{CD}^{+} \mathrm{T}$ cells, including those that are $M$. tuberculosis-specific, resulting in decreased production of IFN- $\gamma, \mathrm{TNF}-\alpha$ and other cytokines that are important in controlling both pathogens [14-18].

Several interventions have been implemented to address the syndemics of HIV-1 and TB. These include routine HIV 
testing among TB patients, increased coverage of cotrimoxazole and isoniazid preventive therapy in HIV-1infected TB patients and earlier diagnosis of HIV and initiation of antiretroviral therapy (ART) [2]. The increased accessibility of ART has significantly improved the clinical outcome of HIV- 1 infected patients and reduces the TB risk by $58-80 \%$ [19]. The positive effects of ART have been described as triphasic, starting with an early and rapid rise of $\mathrm{CD} 45 \mathrm{RO}^{+}$ memory $\mathrm{T}$ cells that redistribute from lymphoid tissues into the plasma within the first month of therapy, followed by a reduction in $\mathrm{T}$ cell activation and improved $\mathrm{CD} 4^{+}$reactivity to recall HIV-1 antigens, and finally the slower replenishment of the CD45RA ${ }^{+}$naïve T cells [20]. In a longitudinal study of coinfected patients sensitized by $M$. tuberculosis, ART led to an increase in central memory $\left(\mathrm{CD} 27^{+} \mathrm{CD} 45 \mathrm{RA}^{-}\right.$and $\mathrm{CD} 27^{+} \mathrm{CCR} 5^{-} \mathrm{CD} 4^{+}$) $\mathrm{T}$ cells by 12 weeks post-treatment, followed by an increase in naïve $\left(\mathrm{CD} 27^{+} \mathrm{CD} 45 \mathrm{RA}^{+}\right) \mathrm{T}$ cells at 36 weeks [21]. A separate longitudinal study confirmed that the polyfunctional effector memory $\left(\mathrm{CD} 27^{-} \mathrm{CD} 45 \mathrm{RO}^{+}\right)$and terminally differentiated memory $\left(\mathrm{CD} 27^{-} \mathrm{CD} 45 \mathrm{RO}^{-}\right) \mathrm{CD}^{+}$ $T$ cells responsive to mycobacterial purified protein derivative (PPD) were restored 12 months post-ART [22].

\section{Immune reconstitution inflammatory syndrome}

Although ART has positive effects through suppression of HIV-1 viral load and restoring $\mathrm{CD}^{+} \mathrm{T}$ cell numbers, this rapid restoration of the immune system can also lead to an undesirable complication known as immune reconstitution inflammatory syndrome (IRIS; also known as immune restoration disease, IRD). IRIS is characterized by a transient but sometimes severe local and systemic inflammatory response directed against a known condition (e.g., opportunistic pathogens or autoimmune diseases) in HIV-1 infected patients shortly after ART initiation. It was first reported in 1992, where HIV-1 coinfected patients developed Mycobacterium avium-complex (MAC) disease with severe lymphadenopathy and high fever following commencement of zidovudine monotherapy [23]. IRIS was subsequently documented to be associated with many different pathogens, including cytomegalovirus (CMV), hepatitis B and C viruses, Cryptococcus, and M. tuberculosis, as well as in cancer (Kaposi's sarcoma and non-Hodgkin's lymphoma) and autoimmune diseases [24].

In a meta-analysis on 54 cohort studies, Muller et al. reviewed the incidence and mortality of IRIS associated with different health conditions [25]. CMV-IRIS was found to have the highest incidence (pooled estimates $37.7 \%$ ), while cryptococcal meningitis-IRIS had the highest mortality (pooled estimates $20.8 \%$ ). More recently, a meta-analysis on 40 studies indicates the overall incidence of IRIS is $\sim 18 \%$ among patients with HIV-associated TB, with mortality attributable to TB-IRIS of $\sim 2 \%$ [26]. Patients with TB meningitis (TBM), however, are at high risk of developing IRIS (47\%), with a mortality rate of up to $30 \%$ following development of IRIS [27-29].

\section{Clinical definition of TB-IRIS}

There is no diagnostic test for TB-IRIS and diagnosis therefore relies on medical history, laboratory data, and clinical presentation. Prior to 2006, a number of TB-IRIS case definitions existed [30-34], but the lack of consensus between these definitions hindered clinical management and research on IRIS. In response to the increase in incidence of this complication in resource-limited settings, over 100 researchers gathered to agree consensus case definitions for ART-associated TB and TB-IRIS [35], which have several times been reinvestigated prospectively and validated [36-39].

There are two forms of TB-IRIS that share clinical features but are distinct in their temporal relationships between tuberculosis diagnosis and treatment and the initiation of ART: paradoxical and unmasking. In paradoxical TB-IRIS, HIV-1patients are diagnosed with TB prior to ART commencement and TB pathology has stabilized or improved during antitubercular therapy. Following ART initiation, patients experience new, recurrent or worsening features of TB, such as lymph node swelling and abscess formation, serositis, and radiographic deterioration [35]. In unmasking TB-IRIS, patients with previously undiagnosed and untreated TB present after initiation of ART and with often marked inflammatory features of TB [35]. Exclusion criteria for both types of TBIRIS include exacerbation of TB due to drug-resistant M. tuberculosis, presence of other opportunistic infections, poor drug adherence, or adverse drug reactions.

\section{Risk factors for TB-IRIS}

Although the underlying mechanisms of TB-IRIS pathogenesis are incompletely elucidated, A few clinical risk factors have been related to developing TB-IRIS. Firstly, patients with low $\mathrm{CD}^{+}{ }^{+} \mathrm{T}$ cell counts at the time of ART initiation, followed by a rapid increase of CD4 counts post-ART, are more likely to develop TB-IRIS [40-43]. This contributes to an exaggerated $\mathrm{T}$ cell response directed to $M$. tuberculosis along with overproduction of both pro- and antiinflammatory cytokines [44]. The second risk factor is a short interval between starting antitubercular therapy and ART [45-47]. The CD4 counts should be taken into consideration when deciding the optimal time to initiate ART. For patients with low $\mathrm{CD}^{+} \mathrm{T}$ cell counts $(<50$ cells $/ \mu \mathrm{l})$, the benefits of early initiation of ART in reducing mortality and opportunistic infections outweigh the risk of IRIS and therefore ART should not be delayed more than 2 weeks. For those with CD4 counts $>50$ cells $/ \mu \mathrm{l}$, ART should be commenced between 2 and 12 weeks after starting TB treatment. Furthermore, dissemination 
of TB infection to extrapulmonary organs appears to increase the risk of TB-IRIS by up to eight-fold, probably due to higher bacterial burden in such cases [48, 49]. TBM is the most severe form of extrapulmonary $\mathrm{TB}$ and in one series accounted for $12 \%$ of all TB-IRIS cases [27]. Finally, high HIV-1 viral load is another risk factor for TB-IRIS [26] and M. tuberculosis culture positivity in the cerebrospinal fluid (CSF) is a risk factor for TBM-IRIS [27].

\section{Management}

The inflammatory response associated with TB-IRIS can be transient and may resolve without specific intervention. However, in many cases there is marked inflammation that, at worst, may result in death. Anecdotal reports of glucocorticoids to reduce inflammation in TB-IRIS [50-52] encouraged a randomized placebo-controlled trial to evaluate TB-IRIS treatment with prednisone [53]. Patients with paradoxical TB-IRIS who received a 4 -week course of prednisone $(1.5 \mathrm{mg} / \mathrm{kg}$ per day for 2 weeks then $0.75 \mathrm{mg} / \mathrm{kg}$ per day for 2 weeks) were found to have reduced need for hospitalization, quicker resolution of symptoms and a better quality of life without excess of severe adverse events, compared to those who received placebo [53]. The beneficial effects of prednisone in reducing the inflammatory reactions in TB-IRIS were associated with more rapid resolution of the elevated C-reactive protein (CRP) and suppression of pro-inflammatory cytokines of innate immune origin [54]. Nevertheless, prednisone should be prescribed and monitored with caution in patients with advanced HIV-1 infection as (albeit outside the context of widespread ART) it associates in some studies with an increase in the risk of HIV-1 related malignancy (such as Kaposi's sarcoma) and recurrent herpes zoster $[55,56]$. Furthermore, as TBIRIS may occur in patients with drug-resistant M. tuberculosis, prednisone therapy should be used with care pending satisfactory optimization of antimicrobial therapy [57].

In addition to glucocorticoids, other anti-inflammatory agents have also been used to treat TB-IRIS or IRIS associated with other pathogens in isolated cases (Table 1). Non-steroidal anti-inflammatory drugs (NSAIDs) have been used to relieve symptoms in non-severe cases of paradoxical TB-IRIS, MAC-IRIS, and cryptococcal-IRIS with lymphadenitis with favorable results [58]. Thalidomide is an immunomodulatory drug with use in cancer and inflammatory diseases. It has been used to treat patients with intractable tuberculomas [59, 60] and alleviated symptoms in steroid-refractory TB-IRIS, TBand cryptococcal-lymphadenitis IRIS, as well as in pediatric neurological TB-IRIS [61-64]. Leukotriene antagonists (e.g., montelukast and zileuton) are used in treatment in asthma and most recently have been proposed as potential host-directed therapy in active TB [65]. Montelukast has been used to treat two cases of steroid-refractory IRIS associated with TB and syphilis and also in a patient with urticarial IRIS vasculitis, with rapid clinical responses [66, 67]. Other drugs such as

Table 1 Drugs used to treat TB-IRIS

\begin{tabular}{|c|c|c|}
\hline Drug/class of drugs & Mechanism of action & Potential side effects \\
\hline Corticosteroids & $\begin{array}{l}\text { At gene level, activate the transcription of anti-inflammatory } \\
\text { mediators and inhibit transcription of pro-inflammatory } \\
\text { genes (e.g., cyclooxygenase and cytokines). At cellular } \\
\text { level, reduce the production of nitric oxide and inhibits } \\
\text { TCR signaling, thereby reducing cell migration, } \\
\text { proliferation and effector function }\end{array}$ & $\begin{array}{l}\text { Increased risk of Kaposi's sarcoma, herpes simplex } \\
\text { and zoster flare. General side effects include } \\
\text { increased risk of infections, hypertension, diabetes, } \\
\text { osteoporosis, ulcers and mental health problems }\end{array}$ \\
\hline NSAIDs & $\begin{array}{l}\text { Relieve pain and reduce inflammation by inhibiting } \\
\text { cyclooxygenase- } 1 \text { and }-2 \text {, thereby reducing the synthesis } \\
\text { of inflammation mediator prostaglandins }\end{array}$ & $\begin{array}{l}\text { Increased risk of gastrointestinal problems such as } \\
\text { ulcers; not recommended in patients with a history } \\
\text { of renal or liver disease }\end{array}$ \\
\hline Thalidomide & $\begin{array}{l}\text { Modulates the production of cytokines and inflammatory } \\
\text { mediators; also stimulates T cells and modulates NK } \\
\text { cell cytotoxicity }\end{array}$ & $\begin{array}{l}\text { Peripheral neuropathy, somnolence, hepatotoxicity, } \\
\text { teratogenicity, skin reactions, constipation, tremor, } \\
\text { mood changes and headache }\end{array}$ \\
\hline $\begin{array}{l}\text { Leukotriene receptor } \\
\text { antagonists }\end{array}$ & $\begin{array}{l}\text { Blocks pro-inflammatory leukotrienes by inhibiting the } \\
\text { 5-lipoxygenase pathway or by antagonizing } \\
\text { cysteinyl-leukotriene type } 1 \text { receptors; inhibit leukocytes } \\
\text { trafficking to the sites of antigen stimulation }\end{array}$ & $\begin{array}{l}\text { Skin reaction, sinus pain, tremors, mood changes, } \\
\text { gastrointestinal problems; may also interact with } \\
\text { rifampicin and antiretroviral drugs }\end{array}$ \\
\hline Pentoxifylline & $\begin{array}{l}\text { A non-selective adenosine receptor antagonist and also } \\
\text { non-selectively inhibits phosphodiesterase, resulting in an } \\
\text { increase in cAMP activity and reduced inflammation. In } \\
\text { addition, it improves erthyocytes deformability, decreases } \\
\text { blood viscosity and inhibits neutrophil adhesion and } \\
\text { activation }\end{array}$ & $\begin{array}{l}\text { Hemorrhage, gastrointestinal problems, nausea, } \\
\text { dizziness, blurred vision, flushing and chest pain }\end{array}$ \\
\hline Hydroxychloroquine & $\begin{array}{l}\text { Blocks activation through TLR and interferes with MHC-II } \\
\text { processing; reduce synthesis of pro-inflammatory cytokines }\end{array}$ & $\begin{array}{l}\text { Blurred vision, somnolence, gastrointestinal problems, } \\
\text { skin rash and lost of appetite }\end{array}$ \\
\hline
\end{tabular}

Drugs with reported use in treating TB-IRIS, their mechanism of actions and side effects are listed 
pentoxifylline and hydroxychloroquine had also been used to treat isolated cases of IRIS associated with different pathogens with some reported benefits [68-71]. Nevertheless, these therapies lack clinical trial data to assess their effectiveness and potential adverse effects in treating TB-IRIS and further rigorous evaluations are required.

Finally, TNF- $\alpha$ inhibitors (infliximab, etanercept, adalimumab ,or certolizumab pegol) are effective in treating inflammation in rheumatoid arthritis, spondyloarthropathies, and Crohn's disease. While TNF- $\alpha$ inhibitors are to be prescribed with caution in patients with latent TB due to increased risk of reactivation, in one case withdrawal of adalimumab led to a life-threatening paradoxical TB reaction and the symptoms resolved when the patient was restarted on adalimumab [72]. In another case study of steroid-refractory TBM, the patient improved upon adalimumab therapy [73]. Similar observations have been reported with another TNF- $\alpha$ inhibitor infliximab, where the patient suffered a debilitating TB paradoxical reaction unresponsive to corticosteroids and cyclophosphamide yet showed a favorable response following three doses of infliximab given at monthly intervals [74]. In a single case study with HIV-related inflammatory cerebral cryptococcoma, patient had improved disease symptoms following treatment with adalimumab along with isoniazid and pyridoxine (to prevent tuberculosis reactivation) [75]. Since elevated levels of TNF- $\alpha$ are associated with TB-IRIS [76, 77], TNF- $\alpha$ inhibitors may offer potential benefits as treatment for TB-IRIS.

\section{Inflammatory reactions in TB-IRIS}

TB-IRIS results from excessive inflammatory reactions against $M$. tuberculosis antigen driven by ART-induced reconstitution of the immune system [44, 78]. Numerous reports have described aspects of the immune responses observed in TB-IRIS, which we will discuss in detail in the following sections.

\section{$\mathrm{CD}^{+} \mathrm{T}$ cells and TCR $\gamma \delta \mathrm{T}$ cells}

Paradoxical TB-IRIS was initially ascribed to acute expansion of the mycobacteria-specific Th1 response following ART commencement [44]. The first patient cohort study on TBIRIS consisted of 19 HIV-TB patients, 7 of whom developed IRIS during the first month of ART. Compared to the nonIRIS patients at 3 months, those with TB-IRIS were found to have significantly higher number of IFN- $\gamma$-producing Th1 cells specific to mycobacterial PPD, but not to M. tuberculosisspecific ESAT antigen or CMV [44]. Furthermore, peripheral blood mononuclear cells (PBMC) from a subset of four patients (three TB-IRIS and one non-IRIS) were stimulated with PPD antigen and those with TB-IRIS secreted significantly higher concentrations of Th1 (IL-2, IL-12, IFN- $\gamma$, and IP$10)$ and other (TNF- $\alpha$, IL-1 $\beta$, IL-6, IL-10, RANTES, and MCP-1) cytokines and chemokines, while Th2 cytokines (IL-4, IL-5, IL-13, and IL15) were not detected [44]. The presence of M. tuberculosis antigen-specific Th1 expansions in TB-IRIS was confirmed in a separate study of 95 HIV-TB patients (35 TB-IRIS, 29 non-IRIS and 31 ART-naïve) [79]. However, not all cases of TB-IRIS were characterized by Th1 expansions and conversely expansions occurred longitudinally during ART in many patients who did not develop TB-IRIS. The proportion of $\mathrm{HLA}-\mathrm{DR}^{+} \mathrm{CD} 71^{+} \mathrm{CD} 4^{+}$and $\mathrm{CD} 8^{+} \mathrm{T}$ cells was similar in TB-IRIS and non-IRIS controls [79]. Two additional studies by Tieu et al. [80] and Elliott et al. [81] utilized interferon-gamma release assay (IGRA) and did not find any difference in IFN- $\gamma$ response in whole blood between patients with paradoxical TB-IRIS and the non-IRIS controls 12 weeks post-ART, although the latter study observed an increase in IFN- $\gamma$ response to PPD 24 weeks post-ART.

Since IRIS commonly occurs in patients who are severely lymphopenic following ART initiation, Sereti and colleagues proposed that the syndrome is contributed by lymphopeniainduced $\mathrm{T}$ cell homeostatic mechanisms, and an imbalance in the regulatory mechanisms occurs irrespective of antigen stimulus [82]. In a longitudinal study of 45 HIV-1-infected patients commencing ART, 16 developed IRIS associated with different etiological causes and were found to have a highly activated, predominantly PD- $1^{+}$HLA-DR ${ }^{+}$and $\mathrm{Ki}^{+} 7^{+}$ $\mathrm{CD}^{+} \mathrm{T}$ cell phenotype prior to and during IRIS, compared to the non-IRIS controls [82]. Moreover, these IRIS patients also had a Th1/Th17-skewed cytokine profile upon polyclonal stimulation and increased PD-1 and Ki67 expression in regulatory $\mathrm{T}$ cells (Treg), suggesting increased activation of effector $\mathrm{T}$ cells due to antigenic exposure. Furthermore, TB-IRIS patients were found to have a significantly higher serum concentration of IL-7 and SCD25 compared to the non-IRIS controls [82, 83], further indicating that TB-IRIS is associated with exaggerated $\mathrm{T}$ cell activation and proliferation. In a follow-up study, it was noted that patients with IRIS related to different pathogens did not have a generalized $\mathrm{T}$ cell dysfunction and the dysregulated $\mathrm{CD} 4{ }^{+} \mathrm{T}$ cell response represented an upsurge of pre-existing responses that were both polyfunctional and targeted exclusively to the opportunistic pathogen, not to HIV-1 itself [84].

In addition to Th1, other $\mathrm{T}$ cell subsets have also been investigated for their potential contribution to TB-IRIS. As mentioned above, Foxp $3^{+} \mathrm{CD}^{+}{ }^{+} \mathrm{T}$ cells (considered as Treg) cells are critical in maintaining $\mathrm{T}$ cell homeostasis [85]. In mice infected with TB, Treg cells expanded and accumulated at the site of infection and contribute to suppression of Th1-type immune responses [86]. Increased circulating Treg frequency was also reported in TB patients, in which blood $\mathrm{CD}^{+} \mathrm{T}$ cells were found to have increased cell surface expression of $\mathrm{CD} 25^{\text {high }}$ and increased mRNA expression of Foxp3 [87]. 
Several studies have investigated whether a dysregulated Treg response may contribute to TB-IRIS and reported conflicting results. Two of these studies found an expansion of Foxp3 $3^{+}$ Tregs in $M$. avium and CMV-associated IRIS, although the ability of these cells to secrete IL-10 appeared to be compromised in vitro [88, 89]. Conversely Meintjes et al. reported an overall low level of Foxp ${ }^{+} \mathrm{T}$ cells among PBMC, with no difference in the percentage of these cells in TB-IRIS and non-IRIS patients [79]. Similar observations were also reported by Antonelli et al.: neither the number nor the frequency of Treg differed when comparing IRIS to non-IRIS patients [82].

The role of TCR $\gamma \delta$ T cells in TB-IRIS has also been explored. TCR $\gamma \delta$ T cells are potent producers of IFN- $\gamma$ and TNF- $\alpha$, possess cytotoxic capacity and release granuleassociated perforin and granzyme B to lyse infected cells upon antigen recognition [90]. They are activated in response to $M$. tuberculosis early after infection and may reduce intracellular bacterial growth [91]. The $\mathrm{V} \delta 2^{+} \mathrm{TCR} \gamma \delta^{+} \mathrm{T}$ cell subset are ascribed a role in adaptive immunity to mycobacterial infection $[92,93]$ and their numbers are restored following successful antitubercular treatment in HIV-1 infected persons [94]. Patients co-infected with HIV-1 and M. tuberculosis, however, have significantly reduced TCR $\gamma \delta$ T cell responses [91]. Compared to non-IRIS patients, those with paradoxical TB-IRIS were found to have significantly higher number of killer immunoglobulin receptor (KIR) ${ }^{-} \mathrm{V} \delta 2^{+} \mathrm{TCR} \gamma \delta^{+} \mathrm{T}$ cells but a lower number of $\mathrm{KIR}^{+} \mathrm{TCR} \gamma \delta^{+} \mathrm{T}$ cells at all timepoints including baseline [95]. This observation indicates independent regulation of different TCR $\gamma \delta$ T cell subsets during IRIS development, with the suggestion that the $\mathrm{KIR}^{-} \mathrm{V} \delta 2^{+} \mathrm{TCR} \gamma \delta^{+}$ subset amplifies the dysregulated immune response to M. tuberculosis, whereas the inhibitory $\mathrm{KIR}^{+} \mathrm{V} \delta 2^{+} \mathrm{TCR} \gamma \delta^{+}$ subset was suppressed.

Together, these data demonstrate a role for $\mathrm{CD}^{+}{ }^{+} \mathrm{T}$ cells and other $\mathrm{T}$ cell subsets in the dysregulated inflammatory response in TB-IRIS. Nevertheless, as some TB-IRIS cases are not associated with $\mathrm{T}$ cell expansion, it remains conjectural whether the $\mathrm{T}$ cell response is the cause, rather than the consequence, of the syndrome.

\section{$\mathrm{CD8}^{+} \mathrm{T}$ cells}

Compared to $\mathrm{CD}^{+}{ }^{+} \mathrm{T}$ cells, there have been very limited studies on the role of $\mathrm{CD}^{+} \mathrm{T}$ cells in TB-IRIS pathogenesis. Two studies showed that the numbers and frequency of $\mathrm{CD}^{+} \mathrm{T}$ cells did not differ between TB-IRIS and non-IRIS patients prior to ART and during IRIS [35, 96]. In contrast, ReyesTeran and colleagues reported that increased frequency of circulating $\mathrm{CD}^{+} \mathrm{T}$ cells is a risk factor for developing IRIS associated with M. tuberculosis and M. avium [97]. Furthermore, the authors reported an expansion of the naïve $\mathrm{CD} 8^{+}$ subpopulation, as well as the $\mathrm{CD} 38^{+} \mathrm{HLA}_{-\mathrm{DR}}{ }^{+} \mathrm{CD} 8^{+} \mathrm{T}$ cells, during TB-IRIS episode [97]. No further phenotyping of the
CD8 $+\mathrm{T}$ cells in the study was performed, thus the precise subpopulation associated with TB-IRIS development was not defined. Furthermore, the functionality of $\mathrm{CD}^{+} \mathrm{T}$ cells has not been investigated in the context of TB-IRIS and their contribution to the syndrome remains unclear.

\section{Soluble mediators}

A feature of TB-IRIS is increased production of both pro- and anti-inflammatory cytokines, which is in turn influenced by the antigen load in patients $[98,99]$. In the study by Tadokera et al., PBMC from paradoxical TB-IRIS patients stimulated with heat-killed $M$. tuberculosis secreted significantly higher concentrations of IL-1 $\beta$, IL-2, IL-6, IL-8, IL-10, IL-12p40, IFN- $\gamma$, GM-CSF, and TNF- $\alpha$, compared to those from the non-IRIS controls [77]. Higher concentrations of IL-6, IL-8, IL-10, IL-12p40, IFN- $\gamma$, and TNF- $\alpha$ were also detected in the serum of the same TB-IRIS patients. Similar observations have been reported by others [100-102]. In a study comparing TB-IRIS patients randomized to prednisone or placebo, the serum concentration of IL-6, IL-10, IL-12p40, IFN- $\gamma$, IP-10, and TNF- $\alpha$ decreased during 4 weeks of prednisone therapy, but not in the placebo group [54], further implying a pathological role for hypercytokinemia in TB-IRIS. IL-6 has been suggested to be a major pathological mediator in TB-IRIS as a higher level of plasma IL-6 and CRP at baseline was associated with subsequent development of TB-IRIS [103]. Barber et al. assessed whether inhibition of IL- 6 can reduce pathology in a murine model with $M$. avium-associated IRIS (see "Animal model" section) and showed that neutralization of IL-6 with a monoclonal antibody reduced CRP levels, alleviated disease pathology and extended survival [104]. Most recently, Ravimohan et al. reported that inflammatory markers increased rapidly in HIV-TB patients with early deaths and in patients who developed TB-IRIS, but the two groups have differential recovery of the adaptive immune system [76]. Patients with early mortality were found to have increased preART plasma concentrations of IL-6, IL-10, TNF- $\alpha$, MCP-1, and eotaxin, but these increases were not accompanied by early recovery of $\mathrm{CD}^{+} \mathrm{T}$ cells. In contrast, the significant increase in the plasma concentrations of IL- 6 and TNF- $\alpha$ following ART initiation paralleled a marked increase in CD4 counts in TB-IRIS patients. Together, the CD4 counts prior to and following ART, along with the concentrations of inflammatory markers such as IL- 6 and TNF- $\alpha$ might have potential use as biomarkers to assist TB-IRIS diagnosis.

Furthermore, plasma or serum concentrations of IL-17 and IL-22 have also been reported to be higher in both paradoxical and unmasking TB-IRIS [100, 105]. Both IL-17 and IL-22 arise from distinct lineages of $\mathrm{T}$ cells and are critical in bridging innate and adaptive immunity in host defense against pathogens at mucosal sites (reviewed in [106]). More recently, elevation of plasma IL-18 at baseline (pre-ART) and during 
TB-IRIS has also been reported [107, 108]. In addition to the excessive release of both pro- and anti-inflammatory cytokines, IP-10 and CCL4 chemokines were also found to be elevated in the plasma of TB-IRIS patients longitudinally over the course of ART $[107,109]$. Similar findings were reported in patients with TBM-IRIS, where the concentrations of an array of chemokines (CXCL1-3, CCL2/3/4, and IP-10) were all significantly higher in the CSF of TBM-IRIS patients compared to non-IRIS TBM patients [110]. The induction of these chemokines suggests an increased chemoattraction of monocytes/macrophages and other immune cells to the site of inflammation, thereby contributing to the pathogenesis of TB-IRIS.

Other inflammatory mediators have also been reported to be elevated in TB-IRIS.

Matrix metalloproteinases (MMPs) are zinc-dependent endopeptidases involved in tissue repair, remodeling and modulation of the immune response $[111,112]$. The concentration of MMP-1 was significantly higher in the lung of TB patients with or without HIV-1 infection [113]. In the context of TBIRIS, PBMC from paradoxical TB-IRIS patients were found to have significantly higher mRNA expression and protein secretion of MMP-1, -3, -7 and -10 than in non-IRIS controls [114]. Following prednisone therapy, the serum concentration of MMP-7 showed a modest reduction, suggesting a specific contribution to pathogenesis. Similarly, in the CSF of TBMIRIS patients, the concentration of MMP-9 was significantly higher compared to non-IRIS TBM patients both pre-ART and post-ART [110]. However, the CSF concentration of MMP-9 did not decrease following antitubercular and corticosteroid therapy and continued to rise following ART initiation. This, together with the poor clinical outcomes, suggests that more potent and specific therapy may be needed for the management of TBM-IRIS.

Finally, deficiency of vitamin $\mathrm{D}_{3}$ is associated with active TB disease [115]. Adjunctive vitamin $\mathrm{D}_{3}$ supplementation can help resolve TB pathology by suppressing antigen-stimulated pro-inflammatory response and inhibiting secretion of MMP$1,-7,-9$ and $-10[116,117]$. While deficient plasma levels of vitamin $\mathrm{D}_{3}$ did not predict the development of TB-IRIS [118], serum concentrations of IL- $1 \beta$, IL- 6 , and IL- 8 were significantly higher at both baseline and during TB-IRIS in vitamin $\mathrm{D}_{3}$-deficient patients who experienced the syndrome [109].

In patients with TBM, concentrations of inflammatory mediators were significantly higher in the CSF than in blood regardless of IRIS status [110]. Individuals who eventually developed TBM-IRIS had elevated CSF concentrations of an array of cytokines, chemokines, MMPs, as well as neutrophil-associated mediators (e.g., S100A8/A9) at both baseline and the time of symptom presentation [110]. Compared to CSF, representative of the neurological compartment, only subtle differences in the concentrations of these analytes were detected in the corresponding blood samples between
TBM-IRIS and non-IRIS. Further studies conducted with materials from IRIS disease sites are likely to be informative.

The potential genetic influence in IRIS predisposition has been investigated in two studies by Price and colleagues. While the small sample size rendered these studies underpowered and inconclusive, they nevertheless provided some pointers that genetic factors might play a role in TB-IRIS. In a study that included nine patients with MAC-associated IRIS and two with TB-IRIS, the frequency of the IL6-174*C polymorphism (36\%) was significantly lower than in the non-IRIS controls (61-71\%) [119]. Furthermore, none of the IRIS patients carried the TNFA- $308 * 2$ polymorphism, while the frequency was $23-52 \%$ in the non-IRIS group. In a cohort study with 17 Cambodian and 19 Indian patients, TB-IRIS was associated with higher frequencies of TNFA-1031*T and SLC11A1 D543*G in Cambodian patients, while higher frequencies of IL18-607* $\mathrm{G}$ and VDR Fokl(F/f)*T were observed in Indian patients [120]. Larger-scale studies would be required to determine with confidence if specific polymorphisms relate to the risk of TB-IRIS, although recruitment to such a study might be difficult.

\section{$B$ cell response}

TB-IRIS is regarded as a cell-mediated disease and little is known about the role played by humoral immunity. Simmoney et al. examined longitudinal antibody responses in a cohort of 24 HIV-TB co-infected patients starting on ART by measuring circulating free and immune-complexed antibodies against $M$. tuberculosis antigens (ManLAM, ESAT-6/CFP10, and PGL-Tb1) [121]. Compared to nonIRIS patients, those with TB-IRIS had a significantly lower level of anti-PGL-Tb1 antibody prior to the episode regardless of CD4 counts or presence of complexed antibodies. There was no difference in the antibody levels against ManLAM or ESAT-6/CFP-10 between TB-IRIS and non-IRIS. A similar result was also reported in another study where the levels of anti-PPD, anti-ManLAM, and anti-38-kDa antigen antibodies did not differ between TB-IRIS and non-IRIS patients prior to ART, or at the time of IRIS [122]. Furthermore, the lineage of M. tuberculosis did not appear to be associated with development of TB-IRIS [121], although this interesting issue is not resolved with certainty.

More recently, a regulatory role for $\mathrm{B}$ cells has been described in TB granulomas in primates, which is mediated via secretion of IL-10 and M. tuberculosis-specific antibodies [123]. Antibodies contribute to immune defense through three mechanisms: neutralization, activation of the complement system, or opsonization. In opsonization, phagocytes expressing Fc $\gamma$ receptors recognize antibody-bound antigens (e.g. M. tuberculosis) and take up the complex into the phagosomes for elimination. Increased expression of $\mathrm{Fc} \gamma$ receptors (FCGR1/2/3) has been reported in almost all transcriptional 
studies on active TB disease [124] and was also identified in microarray profiling of TB-IRIS patients during the IRIS episode [125]. Together, these data suggest that humoral immunity may also contribute to TB-IRIS pathogenesis, although the precise mechanisms remain poorly defined.

\section{Innate immune response}

The role of innate immunity in TB-IRIS pathogenesis has attracted increased attention in recent years. Myeloid cells are the main cells targeted by M. tuberculosis and their pivotal role in antimicrobial defense has been extensively described. Colebunders and colleagues speculated that macrophages in HIV-1 patients with advanced disease, particularly those coinfected with $M$. tuberculosis, are inappropriately activated [126]. Previous studies have reported that stimulation of HIV-1 gp120 alone is sufficient to induce dysfunction and aberrant gene expression in monocytes or monocytesderived macrophages [127-129]. During ART, these immunosuppressive phenotypes are reversed and the functional recovery could result in excessive activation of the macrophages by $M$. tuberculosis antigens [126], subsequently contributing to development of IRIS. Lawn et al. later reported a fatal case of unmasking TB-IRIS, in which $\mathrm{CD} 68^{+}$macrophages were identified as the predominant inflammatory cells in postmortem staining of lung tissue sections [130].

Human monocytes can be categorized into three different subsets: classical $\mathrm{CD} 14^{++} \mathrm{CD} 16^{-}$and non-classical $\mathrm{CD} 14^{+} \mathrm{CD} 16^{+}$and $\mathrm{CD} 14^{\mathrm{dim}} \mathrm{CD} 16^{+}$. The roles played by these subsets in TB-IRIS have recently been explored. Peripheral $\mathrm{CD} 14^{+} \mathrm{CD} 16^{+}$monocytes were isolated from TB-IRIS and non-IRIS patients and transcriptional profiling was performed. Genes associated with the complement system and pattern recognition receptors were found to be differentially abundant in TB-IRIS [131, 132]. The authors further investigated the role of complement in TB-IRIS and reported significantly higher levels of $\mathrm{C} 1 \mathrm{q}$ and $\mathrm{C} 1$-inhibitor of the classical pathway at baseline and an imbalance in their ratio during TB-IRIS onset at 2 weeks post-ART. Activation of the complement system is known to trigger opsonization and killing of pathogens as well as recruitment of inflammatory cells [133]. In another study that examined TB-IRIS patients from South India and South Africa, TB-IRIS was associated with increased plasma concentrations of sCD14, sCD163, and soluble tissue factor, all of which are markers of monocyte activation [134]. Furthermore, patients with TB-IRIS lacked $\mathrm{CD} 14^{\mathrm{dim}} \mathrm{CD} 16^{+}$monocytes while the frequency of $\mathrm{CD} 14^{++} \mathrm{CD} 16^{-}$monocytes were significantly higher than in non-IRIS patients. $\mathrm{CD} 14^{++} \mathrm{CD} 16^{-}$monocytes have high expression of the activation marker CD163 and were found to be closely associated with plasma levels of systemic proinflammatory markers CRP, IL-6, TNF- $\alpha$, and soluble tissue factor (CD142) prior to ART initiation and during TB-IRIS
[134]. Together, these data point towards a pathogenic role for both classic and non-classical monocytes in TB-IRIS and the mechanisms mediated by these cells should be investigated further.

In addition to macrophages/monocytes, natural killer (NK) cells and invariant natural killer T (iNKT) cells may also contribute to TB-IRIS pathogenesis. Activated NK cells can protect against $M$. tuberculosis either directly by lysing infected monocytes and antigen-specific Treg [135, 136], or indirectly by restoring the frequency of $M$. tuberculosis-specific $\mathrm{CD} 8^{+} \mathrm{IFN}-\gamma^{+} \mathrm{T}$ cells [137]. Patients with unmasking TBIRIS were found to have increased NK cell activation and plasma concentrations of CRP and IL-8, compared to nonIRIS or HIV-1-monoinfected controls [138]. In another cohort of 128 co-infected patients from Cambodia, baseline NK cell degranulation capacity was significantly higher in those who eventually developed paradoxical TB-IRIS, but this difference was abrogated following ART initiation, possibly due to regulatory feedback mechanisms or the internalization of NK receptors following ligand binding [139]. Finally, microarray analysis performed on M. tuberculosis-stimulated PBMC isolated from patients identified an overabundance of granzyme $\mathrm{B}$ and perforin transcripts in TB-IRIS, validated at the protein level [96]. The increased secretion of perforin appeared to be contributed by an increased number of $\mathrm{CD}^{+} \mathrm{V} \alpha 24^{+}$iNKT cells. Activation of CD1d-restricted iNKT cells has previously been shown to protect mice from M. tuberculosis infection via a yet unknown mechanism [140]. Further studies are needed to address the role of cytotoxic cells in TB-IRIS.

Neutrophils also appear to have a significant role in the pathogenesis of the highly compartmentalized TBM-IRIS. Active TB disease in HIV-1 uninfected persons is characterized by a type I interferon-inducible, neutrophil-driven transcriptomic signature [141]. Mice lacking IFN1 receptor were protected from TB-induced death with reduced recruitment of neutrophils and inflammatory macrophages to the site of infection [142]. In a cohort of HIV-1-infected South African patients diagnosed with TBM, those who did not develop TBM-IRIS but who were TB culture positive in their CSF showed similar inflammatory response as the TBM-IRIS patients both at the time of TBM diagnosis and 2 weeks postART [88]. However, TBM-IRIS was specifically associated with elevated neutrophil counts in CSF and increased expression of the neutrophil mediators S100A8/9 [27, 110].

Most recently, we have employed transcriptomic profiling of whole blood to investigate potential mechanisms that underlie TB-IRIS pathogenesis. In a longitudinal study whose endpoint was the development of TB-IRIS, we closely tracked responses at various timepoints prior to and following ART commencement (within days of starting ART and up to the median time of IRIS occurrence at 2 weeks). We identified transcripts of TLR signaling and activation of inflammasomes to be prominent in the blood of TB-IRIS patients (Table 2) 
Table 2 Canonical pathways associated with TB-IRIS

\begin{tabular}{lll}
\hline $\begin{array}{l}\text { Top canonical pathways associated } \\
\text { with TB-IRIS }\end{array}$ & $p$ value & Regulation \\
\hline Inflammasome activation & $2.01 \mathrm{E}-04$ & $\mathrm{Up}$ \\
Toll-like receptor signaling & $2.01 \mathrm{E}-04$ & $\mathrm{Up}$ \\
Endothelin-1 signaling & $3.84 \mathrm{E}-04$ & $\mathrm{Up}$ \\
$\begin{array}{l}\text { Role of pattern recognition receptors } \\
\text { in bacteria and virus recognition }\end{array}$ & $8.83 \mathrm{E}-04$ & $\mathrm{Up}$ \\
IL-1 signaling & $8.83 \mathrm{E}-04$ & $\mathrm{Up}$
\end{tabular}

Microarray profiling using whole blood from a cohort of TB-IRIS and TB non-IRIS patients was performed and differentially abundant transcripts associated with TB-IRIS were identified. Functional analysis by Ingenuity Pathway Analysis (IPA) indicates that these differentially abundant transcripts overrepresented innate signaling pathways, including inflammasome activation, toll-like receptor signaling and IL-1 signaling, suggesting that innate immunity plays a significant role in TB-IRIS pathogenesis

[125]. Both TLR2 and TLR4 have been shown to recognize M. tuberculosis antigen. Mice lacking TLR4 have reduced capacity to eliminate $M$. tuberculosis from the lungs and succumbed to disease sooner than wild-type controls [143]. A separate mouse study showed that in high-dose aerosol infection, TLR2 is critical in mediating innate defense against M. tuberculosis infection [144]. Furthermore, TLR2 was

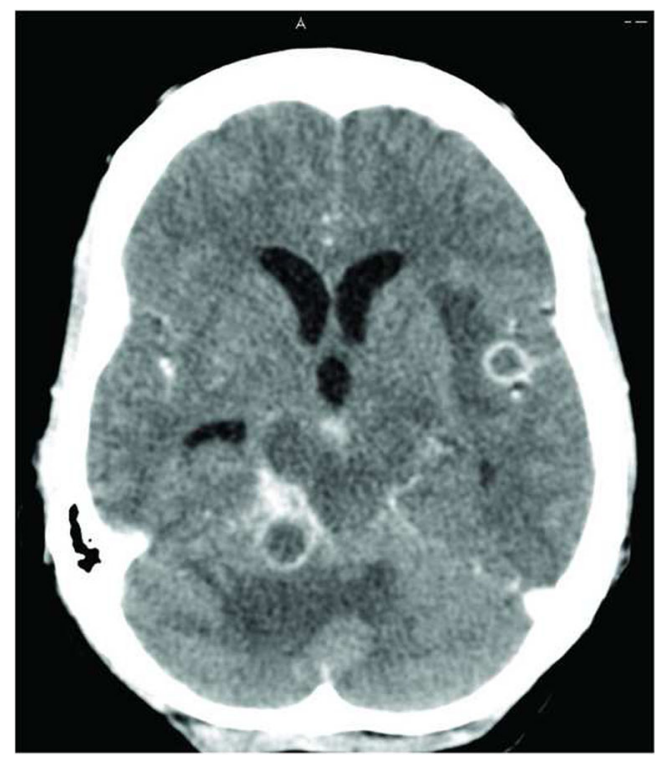

Fig. 1 Contrast-enhanced axial computed tomography (CT) image of TBM-IRIS. CT image showing multiple ring-enhancing lesions with surrounding edema and hydrocephalus in a 41-year-old woman. The patient previously presented with TBM (CSF TB culture was positive for M. tuberculosis susceptible to rifampicin and isoniazid) 10 weeks prior to this presentation. At that time, she was started on TB treatment and ART was initiated 9 weeks later. One week after initiating ART, the patient developed recurrent headaches and this CT was performed 2 weeks later. The recurrent symptoms and these CT findings were ascribed to TBM-IRIS and the patient was treated with corticosteroids with symptom improvement. Image provided by Dr. Suzaan Marais previously reported to express at higher baseline levels in myeloid dendritic cells and monocytes in patients with paradoxical and unmasking TB-IRIS, compared to non-IRIS, and its expression remained higher even at 24 weeks post-ART initiation [145]. This observation suggests that dysregulated signaling via TLR2 mediates the inflammatory reactions observed in TB-IRIS. Indeed, when we inhibited MyD88 (the downstream adaptor of TLR2) in patient's PBMC in vitro, secretion of pro-inflammatory cytokines was markedly reduced specifically in TB-IRIS patients [125]. The production of IL-1 in TB-IRIS appeared to be dependent on

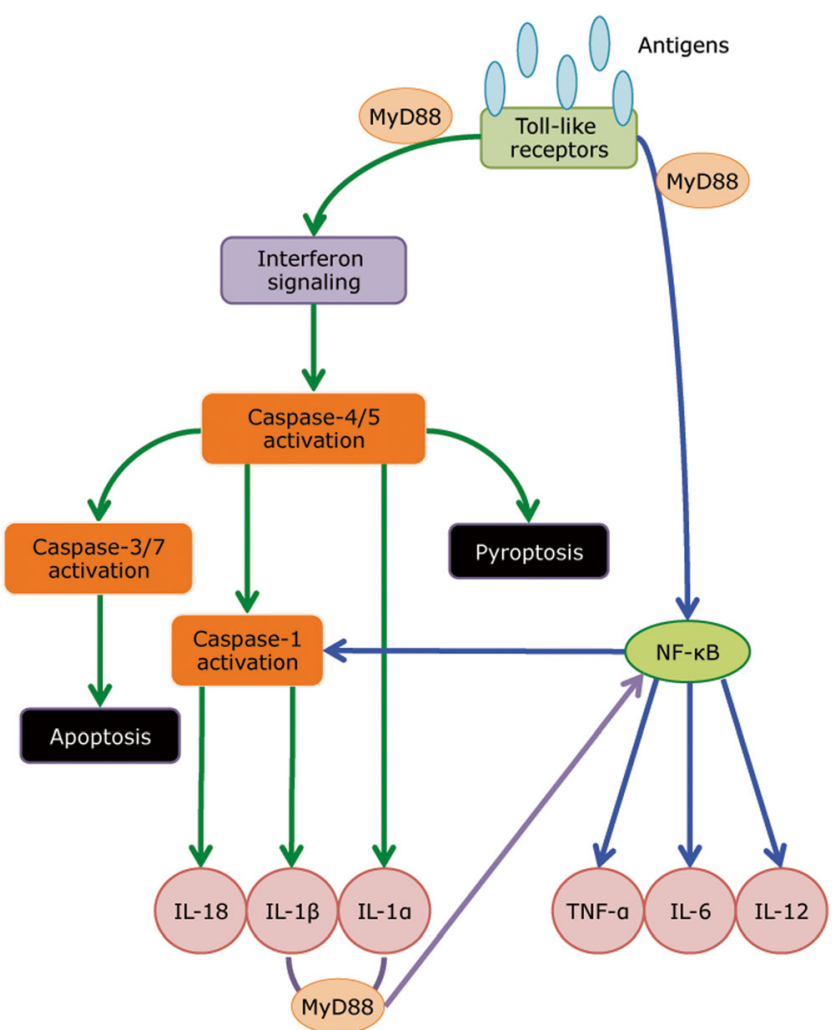

Fig. 2 A model of innate receptor signaling in mediating TB-IRIS pathogenesis. Microarray profiling revealed that TLR signaling and inflammasome activation are critical in mediating TB-IRIS pathogenesis (Table 2) [125]. Our proposed model begins with M. tuberculosis antigen recognition by surface-expressing TLRs, which triggers the downstream signaling cascade with adaptor molecules such as MyD88 and IRAK4 to activate IRF7, thereby triggering the production of type I IFN. Paracrine signaling of Type I IFN to IFNAR recruits and phosphorylates STAT1/2 dimers, leading to further recruitment of IRF9 and the formation of ISGF3, thereby inducing pro-caspase-11 (caspase-4/5 in human) and AIM-2 inflammasome (caspase-1). Caspase-11 cleaves IL-1 $\alpha$ into its mature form and can lead to pyroptosis. The noncanonical inflammasome (caspase-11) can also activate the canonical inflammasome (caspase-1), which cleaves IL-1 $\beta$ and IL-18 into their mature form. Alternatively, TLR signaling via MyD88 can also activate NF-kb via the TAK1/IKK complex. Activation of NF- $\mathrm{kb}$ triggers the production of an array of cytokines, including TNF- $\alpha$, IL- 6 and IL-12. In addition, NF- $k b$ can also activates NLRP $1 / 3$ inflammasomes and subsequently leads to the production of IL- $1 \beta$ and IL-18 
inflammasome activation. In vitro inhibition of Caspase-1/4/5 in PBMC from TB-IRIS patients reduced IL-1 secretion, probably due to disruption in the cleavage from immature to mature form. Together, these data demonstrate the central role played by innate receptor signaling in mediating TB-IRIS pathogenesis and offer some mechanistic insights on the disease (Figs. 1 and 2).

\section{Animal model}

Since HIV-1 does not readily infect non-primates, studying mycobacteria-associated IRIS in small animal models poses a challenge. Thus far, only one murine model on IRIS has been reported using a TCR $\alpha$ knockout mouse chronically infected $M$. avium infection [146]. To recapitulate the $\mathrm{CD} 4^{+} \mathrm{T}$ cell reconstitution observed in TB-IRIS patients, purified $\mathrm{CD}^{+} \mathrm{T}$ cells from naïve mice were injected into $\mathrm{T}$ celldeficient $M$. avium-infected TCR $\alpha$ knockout mice, which led to impaired lung function, severe wasting symptoms and increased mortality within 3 weeks of T cell transfer. In contrast, transfer of $\mathrm{CD}^{+} \mathrm{T}$ cells into wild-type chronically infected mice or TCR $\alpha$ knockout mice prior to $M$. avium infection did not cause any disease. Unexpectedly, the nonlymphopenic OT-II mice were also found to be susceptible to developing reconstitution disease induced by transfer of $M$. avium-specific $\mathrm{CD}^{+} \mathrm{T}$ cells, indicating that the reconstitution disease did not require a lymphopenic environment. In addition, there were two- to five-fold fewer donor $\mathrm{CD}^{+}{ }^{+} \mathrm{T}$ cells recovered from infected compared with naïve recipients. Instead of spontaneous proliferation of $\mathrm{CD}^{+}{ }^{+} \mathrm{T}$ cells in $\mathrm{T}$ cell-deficient environment, the model was associated with impaired, rather than exaggerated, T cell expansion. Furthermore, both antigen recognition and secretion of IFN- $\gamma$ by the grafted $\mathrm{CD} 4^{+} \mathrm{T}$ cells were necessary for disease induction, which correlated with the large increase in the population of $\mathrm{CD}_{11} \mathrm{~b}^{+}$ myeloid cells in the lungs and blood. While this model recapitulates the CD4 restoration characteristic in IRIS, it requires a high-dose of $M$. avium infection leading to bacterial burden that is very high. Furthermore, the model does not capture the immunosuppressive phenotype of monocytes and macrophages induced by HIV-1. Several humanized mouse models have been developed for HIV1 , some of which are able to support persistent viral infection and gradual $\mathrm{CD} 4^{+} \mathrm{T}$ cells decline that mimics human infection [147]. Non-human primates which share close physiology to humans have also been extensively used to study HIV-1 and TB infection, but not yet applied to TB-IRIS. While these models may better recapitulate the overall immune aspects of TB-IRIS, the high cost of performing such studies is a deterrent.

\section{Concluding remarks}

Although TB-IRIS was first described almost 20 years ago with many subsequent case reports, the underlying mechanisms that mediate the disease pathology remain to be fully elucidated. There remains a lack of biomarkers to accurately diagnose and track the syndrome, particularly in resourcelimited settings. The difficulty in studying the underlying mechanisms of TB-IRIS pathogenesis is further complicated by the absence of an animal model that can recapitulate different aspects of the immune defects observed in TB-IRIS, as well as challenges, both practically and ethically, to recruit appropriate controls groups: those who are infected only with HIV-1 or TB, treated and untreated with ART and antitubercular drugs and healthy controls. While a set of consensus guidelines adopted in recent years has helped to standardize TB-IRIS diagnosis and treatment for systematic comparison, our understanding on the pathogenesis remains incomplete. Finally, although corticosteroids such as prednisone can alleviate the symptoms and accelerate clinical improvement, they also have undesirable side effects and drugs targeting specific pathological pathways should be explored. Our group and others have recently utilized transcriptomic approaches to study the underlying mechanisms mediating TB-IRIS and the results from these studies offered insights on some of the immunological pathways involved that may guide future directions for host-directed therapy.

Acknowledgments We would like to thank Dr. Suzaan Marais for providing us with CT image on TBM-IRIS. This work was supported by the UK MRC (U1175.02.002.00014.01), Wellcome Trust (references 081667, 098316, 097254, 104803); the European Union (PIRSES-GA2011-295214 and FP7 HEALTH-F3-2012-305578); the National Research Foundation of South Africa $(96841,64787)$ and the Medical Research Council of South Africa.

Open Access This article is distributed under the terms of the Creative Commons Attribution 4.0 International License (http:// creativecommons.org/licenses/by/4.0/), which permits unrestricted use, distribution, and reproduction in any medium, provided you give appropriate credit to the original author(s) and the source, provide a link to the Creative Commons license, and indicate if changes were made.

\section{References}

1. WHO (2014) Global Health Observatory (GHO) data. http:// www.who.int/gho/hiv/en/

2. WHO (2014) World Health Organization: Global Tuberculosis Report 2014. http://www.who.int/tb/publications/global_report/en/

3. Kony SJ, Hane AA, Larouze B, Samb A, Cissoko S, Sow PS et al (2000) Tuberculosis-associated severe CD4+ T-lymphocytopenia in HIV-seronegative patients from Dakar. SIDAK Research Group. J Infect 41:167-171

4. Pilheu JA, De Salvo MC, Gonzalez J, Rey D, Elias MC, Ruppi MC (1997) CD4+ T-lymphocytopenia in severe pulmonary 
tuberculosis without evidence of human immunodeficiency virus infection. Int J Tuberc Lung Dis 1:422-426

5. Whalen C, Horsburgh CR, Hom D, Lahart C, Simberkoff M, Ellner J (1995) Accelerated course of human immunodeficiency virus infection after tuberculosis. Am J Respir Crit Care Med 151: $129-135$

6. WHO (2015) A guide to monitoring and evaluation for collaborative TB/HIV activities. http://apps.who.int/iris/bitstream/10665/ 150627/1/9789241508278 eng.pdf?ua=1

7. Diedrich CR, Flynn JL (2011) HIV-1/Mycobacterium tuberculosis coinfection immunology: how does HIV-1 exacerbate tuberculosis? Infect Immun 79:1407-1417

8. Hoshino Y, Hoshino S, Gold JA, Raju B, Prabhakar S, Pine R et al (2007) Mechanisms of polymorphonuclear neutrophil-mediated induction of HIV-1 replication in macrophages during pulmonary tuberculosis. J Infect Dis 195:1303-1310

9. Hoshino Y, Nakata K, Hoshino S, Honda Y, Tse DB, Shioda T et al (2002) Maximal HIV-1 replication in alveolar macrophages during tuberculosis requires both lymphocyte contact and cytokines. J Exp Med 195:495-505

10. Lawn SD, Pisell TL, Hirsch CS, Wu M, Butera ST, Toossi Z (2001) Anatomically compartmentalized human immunodeficiency virus replication in HLA-DR+ cells and CD14+ macrophages at the site of pleural tuberculosis coinfection. J Infect Dis 184: $1127-1133$

11. Nakata K, Rom WN, Honda Y, Condos R, Kanegasaki S, Cao Y et al (1997) Mycobacterium tuberculosis enhances human immunodeficiency virus-1 replication in the lung. Am J Respir Crit Care Med 155:996-1003

12. Kumawat K, Pathak SK, Spetz AL, Kundu M, Basu J (2010) Exogenous Nef is an inhibitor of Mycobacterium tuberculosisinduced tumor necrosis factor-alpha production and macrophage apoptosis. J Biol Chem 285:12629-12637

13. Patel NR, Zhu J, Tachado SD, Zhang J, Wan Z, Saukkonen J et al (2007) HIV impairs TNF-alpha mediated macrophage apoptotic response to Mycobacterium tuberculosis. J Immunol 179:69736980

14. Geldmacher C, Schuetz A, Ngwenyama N, Casazza JP, Sanga E, Saathoff E et al (2008) Early depletion of Mycobacterium tuberculosis-specific T helper 1 cell responses after HIV-1 infection. J Infect Dis 198:1590-1598

15. Hertoghe T, Wajja A, Ntambi L, Okwera A, Aziz MA, Hirsch C et al (2000) T cell activation, apoptosis and cytokine dysregulation in the (co)pathogenesis of HIV and pulmonary tuberculosis (TB). Clin Exp Immunol 122:350-357

16. Kalsdorf B, Scriba TJ, Wood K, Day CL, Dheda K, Dawson R et al (2009) HIV-1 infection impairs the bronchoalveolar T-cell response to mycobacteria. Am J Respir Crit Care Med 180: $1262-1270$

17. Mendonca M, Tanji MM, Silva LC, Silveira GG, Oliveira SC, Duarte AJ et al (2007) Deficient in vitro anti-mycobacterial immunity despite successful long-term highly active antiretroviral therapy in HIV-infected patients with past history of tuberculosis infection or disease. Clin Immunol 125:60-66

18. Zhang M, Gong J, Iyer DV, Jones BE, Modlin RL, Barnes PF (1994) $\mathrm{T}$ cell cytokine responses in persons with tuberculosis and human immunodeficiency virus infection. J Clin Invest 94: 2435-2442

19. Suthar AB, Lawn SD, del Amo J, Getahun H, Dye C, Sculier D et al (2012) Antiretroviral therapy for prevention of tuberculosis in adults with HIV: a systematic review and meta-analysis. PLoS Med 9, e1001270

20. Autran B, Carcelain G, Li TS, Blanc C, Mathez D, Tubiana R et al (1997) Positive effects of combined antiretroviral therapy on CD4+ T cell homeostasis and function in advanced HIV disease. Science 277:112-116
21. Wilkinson KA, Seldon R, Meintjes G, Rangaka MX, Hanekom WA, Maartens G et al (2009) Dissection of regenerating T-Cell responses against tuberculosis in HIV-infected adults sensitized by Mycobacterium tuberculosis. Am J Respir Crit Care Med 180: 674-683

22. Sutherland JS, Young JM, Peterson KL, Sanneh B, Whittle HC, Rowland-Jones SL et al (2010) Polyfunctional CD4(+) and CD8(+) T cell responses to tuberculosis antigens in HIV-1infected patients before and after anti-retroviral treatment. J Immunol 184:6537-6544

23. French MA, Mallal SA, Dawkins RL (1992) Zidovudine-induced restoration of cell-mediated immunity to mycobacteria in immunodeficient HIV-infected patients. Aids 6:1293-1297

24. Lawn SD, Bekker LG, Miller RF (2005) Immune reconstitution disease associated with mycobacterial infections in HIV-infected individuals receiving antiretrovirals. Lancet Infect Dis 5:361-373

25. Muller M, Wandel S, Colebunders R, Attia S, Furrer H, Egger M et al (2010) Immune reconstitution inflammatory syndrome in patients starting antiretroviral therapy for HIV infection: a systematic review and meta-analysis. Lancet Infect Dis 10:251-261

26. Namale PE, Abdullahi LH, Fine S, Kamkuemah M, Wilkinson RJ, Meintjes G (2015) Paradoxical TB-IRIS in HIV-infected adults: a systematic review and meta-analysis. Future Microbiol 10:10771099

27. Marais S, Meintjes G, Pepper DJ, Dodd LE, Schutz C, Ismail Z et al (2013) Frequency, severity, and prediction of tuberculous meningitis immune reconstitution inflammatory syndrome. Clin Infect Dis 56:450-460

28. Asselman V, Thienemann F, Pepper DJ, Boulle A, Wilkinson RJ, Meintjes G et al (2010) Central nervous system disorders after starting antiretroviral therapy in South Africa. Aids 24:2871-2876

29. Pepper DJ, Marais S, Maartens G, Rebe K, Morroni C, Rangaka MX et al (2009) Neurologic manifestations of paradoxical tuberculosis-associated immune reconstitution inflammatory syndrome: a case series. Clin Infect Dis 48:e96-e107

30. Colebunders R, John L, Huyst V, Kambugu A, Scano F, Lynen L (2006) Tuberculosis immune reconstitution inflammatory syndrome in countries with limited resources. Int J Tuberc Lung Dis 10:946-953

31. French MA, Price P, Stone SF (2004) Immune restoration disease after antiretroviral therapy. Aids 18:1615-1627

32. Robertson J, Meier M, Wall J, Ying J, Fichtenbaum CJ (2006) Immune reconstitution syndrome in HIV: validating a case definition and identifying clinical predictors in persons initiating antiretroviral therapy. Clin Infect Dis 42:1639-1646

33. Shelburne SA 3rd, Hamill RJ, Rodriguez-Barradas MC, Greenberg SB, Atmar RL, Musher DW et al (2002) Immune reconstitution inflammatory syndrome: emergence of a unique syndrome during highly active antiretroviral therapy. Medicine 81: 213-227

34. Shelburne SA, Montes M, Hamill RJ (2006) Immune reconstitution inflammatory syndrome: more answers, more questions. J Antimicrob Chem 57:167-170

35. Meintjes G, Lawn SD, Scano F, Maartens G, French MA, Worodria W et al (2008) Tuberculosis-associated immune reconstitution inflammatory syndrome: case definitions for use in resource-limited settings. Lancet Infect Dis 8:516-523

36. Eshun-Wilson I, Havers F, Nachega JB, Prozesky HW, Taljaard JJ, Zeier MD et al (2010) Evaluation of paradoxical TB-associated IRIS with the use of standardized case definitions for resourcelimited settings. J Int Assoc Phys AIDS Care 9:104-108

37. Haddow LJ, Moosa MY, Easterbrook PJ (2010) Validation of a published case definition for tuberculosis-associated immune reconstitution inflammatory syndrome. Aids 24:103-108

38. Haddow LJ, Easterbrook PJ, Mosam A, Khanyile NG, Parboosing R, Moodley P et al (2009) Defining immune reconstitution 
inflammatory syndrome: evaluation of expert opinion versus 2 case definitions in a South African cohort. Clin Infect Dis 49: 1424-1432

39. Sharma SK, Dhooria S, Barwad P, Kadhiravan T, Ranjan S, Miglani S et al (2010) A study of TB-associated immune reconstitution inflammatory syndrome using the consensus case-definition. Indian J Med Res 131:804-808

40. French MA, Lenzo N, John M, Mallal SA, McKinnon EJ, James IR et al (2000) Immune restoration disease after the treatment of immunodeficient HIV-infected patients with highly active antiretroviral therapy. HIV Med 1:107-115

41. Jevtovic DJ, Salemovic D, Ranin J, Pesic I, Zerjav S, DjurkovicDjakovic O (2005) The prevalence and risk of immune restoration disease in HIV-infected patients treated with highly active antiretroviral therapy. HIV Med 6:140-143

42. Lawn SD, Myer L, Bekker LG, Wood R (2007) Tuberculosisassociated immune reconstitution disease: incidence, risk factors and impact in an antiretroviral treatment service in South Africa. Aids 21:335-341

43. Ratnam I, Chiu C, Kandala NB, Easterbrook PJ (2006) Incidence and risk factors for immune reconstitution inflammatory syndrome in an ethnically diverse HIV type 1-infected cohort. Clin Infect Dis 42:418-427

44. Bourgarit A, Carcelain G, Martinez V, Lascoux C, Delcey V, Gicquel B et al (2006) Explosion of tuberculin-specific Th1-responses induces immune restoration syndrome in tuberculosis and HIV co-infected patients. Aids 20:F1-F7

45. Abdool Karim SS, Naidoo K, Grobler A, Padayatchi N, Baxter C, Gray AL et al (2011) Integration of antiretroviral therapy with tuberculosis treatment. N Engl J Med 365:1492-1501

46. Blanc FX, Sok T, Laureillard D, Borand L, Rekacewicz C, Nerrienet E et al (2011) Earlier versus later start of antiretroviral therapy in HIV-infected adults with tuberculosis. N Engl J Med 365:1471-1481

47. Havlir DV, Kendall MA, Ive P, Kumwenda J, Swindells S, Qasba SS et al (2011) Timing of antiretroviral therapy for HIV-1 infection and tuberculosis. N Engl J Med 365:1482-1491

48. Burman W, Weis S, Vernon A, Khan A, Benator D, Jones B et al (2007) Frequency, severity and duration of immune reconstitution events in HIV-related tuberculosis. Int J Tuberc Lung Dis 11: $1282-1289$

49. Manosuthi W, Kiertiburanakul S, Phoorisri T, Sungkanuparph S (2006) Immune reconstitution inflammatory syndrome of tuberculosis among HIV-infected patients receiving antituberculous and antiretroviral therapy. J Infect 53:357-363

50. Benson CA, Kaplan JE, Masur H, Pau A, Holmes KK, Cdc et al (2004) Treating opportunistic infections among HIV-infected adults and adolescents: recommendations from $\mathrm{CDC}$, the National Institutes of Health, and the HIV Medicine Association/ Infectious Diseases Society of America. MMWR Recommend Rep 53:1-112

51. Blumberg HM, Burman WJ, Chaisson RE, Daley CL, Etkind SC, Friedman LN et al (2003) American Thoracic Society/Centers for Disease Control and Prevention/Infectious Diseases Society of America: treatment of tuberculosis. Am J Respir Crit Care Med 167:603-662

52. Breen RA, Smith CJ, Bettinson H, Dart S, Bannister B, Johnson MA et al (2004) Paradoxical reactions during tuberculosis treatment in patients with and without HIV co-infection. Thorax 59: 704-707

53. Meintjes G, Wilkinson RJ, Morroni C, Pepper DJ, Rebe K, Rangaka MX et al (2010) Randomized placebo-controlled trial of prednisone for paradoxical tuberculosis-associated immune reconstitution inflammatory syndrome. Aids 24:2381-2390

54. Meintjes G, Skolimowska KH, Wilkinson KA, Matthews K, Tadokera R, Conesa-Botella A et al (2012) Corticosteroid- modulated immune activation in the tuberculosis immune reconstitution inflammatory syndrome. Am J Respir Crit Care Med 186:369-377

55. Elliott AM, Luzze H, Quigley MA, Nakiyingi JS, Kyaligonza S, Namujju PB et al (2004) A randomized, double-blind, placebocontrolled trial of the use of prednisolone as an adjunct to treatment in HIV-1-associated pleural tuberculosis. J Infect Dis 190: $869-878$

56. Volkow PF, Cornejo P, Zinser JW, Ormsby CE, Reyes-Teran G (2008) Life-threatening exacerbation of Kaposi's sarcoma after prednisone treatment for immune reconstitution inflammatory syndrome. Aids 22:663-665

57. Meintjes G, Rangaka MX, Maartens G, Rebe K, Morroni C, Pepper DJ et al (2009) Novel relationship between tuberculosis immune reconstitution inflammatory syndrome and antitubercular drug resistance. Clin Infect Dis 48:667-676

58. AIDSInfo (2009) Guidelines for prevention and treatment of opportunistic Infections in HIV-infected adults and adolescents

59. Roberts MT, Mendelson M, Meyer P, Carmichael A, Lever AM (2003) The use of thalidomide in the treatment of intracranial tuberculomas in adults: two case reports. J Infect 47:251-255

60. Schoeman JF, Fieggen G, Seller N, Mendelson M, Hartzenberg B (2006) Intractable intracranial tuberculous infection responsive to thalidomide: report of four cases. J Child Neurol 21:301-308

61. Brunel AS, Reynes J, Tuaillon E, Rubbo PA, Lortholary O, Montes B et al (2012) Thalidomide for steroid-dependent immune reconstitution inflammatory syndromes during AIDS. Aids 26: 2110-2112

62. Fernandes GC, Vieira MA, Lourenco MC, Gadelha AJ, Coura LC, Rolla VC (2002) Inflammatory paradoxical reaction occurring in tuberculosis patients treated with HAART and rifampicin. Rev Inst Med Trop Sao Paulo 44:113-114

63. Lortholary O, Fontanet A, Memain N, Martin A, Sitbon K, Dromer F et al (2005) Incidence and risk factors of immune reconstitution inflammatory syndrome complicating HIVassociated cryptococcosis in France. Aids 19:1043-1049

64. van Toorn R, Rabie H, Dramowski A, Schoeman JF (2012) Neurological manifestations of TB-IRIS: a report of 4 children. Eur J Paediatr Neurol 16:676-682

65. Mayer-Barber KD, Andrade BB, Oland SD, Amaral EP, Barber DL, Gonzales J et al (2014) Host-directed therapy of tuberculosis based on interleukin-1 and type I interferon crosstalk. Nature 511: 99-103

66. Hardwick C, White D, Morris E, Monteiro EF, Breen RA, Lipman M (2006) Montelukast in the treatment of HIV associated immune reconstitution disease. Sex Transm Infect 82:513-514

67. Lipman MC, Carding SK (2007) Successful drug treatment of immune reconstitution disease with the leukotriene receptor antagonist, montelukast: a clue to pathogenesis? Aids 21: 383-384

68. Bell HC, Heath CH, French MA (2005) Pulmonary Mycobacterium celatum immune restoration disease: immunopathology and response to corticosteroid therapy. Aids 19: 2047-2049

69. Boelaert JR, Goddeeris KH, Vanopdenbosch LJ, Casselman JW (2004) Relapsing meningitis caused by persistent cryptococcal antigens and immune reconstitution after the initiation of highly active antiretroviral therapy. Aids 18:1223-1224

70. John M, French MA (1998) Exacerbation of the inflammatory response to Mycobacterium tuberculosis after antiretroviral therapy. Med J Aust 169:473-474

71. Wallis RS, Johnson JL, Okwera A, Nsubuga P, Whalen CC, Mugerwa RD et al (1998) Pentoxifylline in human immunodeficiency virus- positive tuberculosis: safety at 4 years. J Infect Dis 178:1861 
72. Wallis RS, van Vuuren C, Potgieter S (2009) Adalimumab treatment of life-threatening tuberculosis. Clin Infect Dis 48:14291432

73. Lee HS, Lee Y, Lee SO, Choi SH, Kim YS, Woo JH et al (2012) Adalimumab treatment may replace or enhance the activity of steroids in steroid-refractory tuberculous meningitis. J Infect Chemother 18:555-557

74. Blackmore TK, Manning L, Taylor WJ, Wallis RS (2008) Therapeutic use of infliximab in tuberculosis to control severe paradoxical reaction of the brain and lymph nodes. Clin Infect Dis 47:e83-e85

75. Sitapati AM, Kao CL, Cachay ER, Masoumi H, Wallis RS, Mathews WC (2010) Treatment of HIV-related inflammatory cerebral cryptococcoma with adalimumab. Clin Infect Dis 50:e7e10

76. Ravimohan S, Tamuhla N, Steenhoff AP, Letlhogile R, Nfanyana K, Bellamy SL et al (2015) Immunological profiling of tuberculosis-associated immune reconstitution inflammatory syndrome and non-immune reconstitution inflammatory syndrome death in HIV-infected adults with pulmonary tuberculosis starting antiretroviral therapy: a prospective observational cohort study. Lancet Infect Dis 15:429-438

77. Tadokera R, Meintjes G, Skolimowska KH, Wilkinson KA, Matthews K, Seldon R et al (2011) Hypercytokinaemia accompanies HIV-tuberculosis immune reconstitution inflammatory syndrome. Eur Respir J 37:1248-1259

78. Breton G, Duval X, Estellat C, Poaletti X, Bonnet D, Mvondo Mvondo D et al (2004) Determinants of immune reconstitution inflammatory syndrome in HIV type 1-infected patients with tuberculosis after initiation of antiretroviral therapy. Clin Infect Dis 39:1709-1712

79. Meintjes G, Wilkinson KA, Rangaka MX, Skolimowska K, van Veen K, Abrahams M et al (2008) Type 1 helper T cells and FoxP3-positive T cells in HIV-tuberculosis-associated immune reconstitution inflammatory syndrome. Am J Respir Crit Care Med 178:1083-1089

80. Tieu HV, Ananworanich J, Avihingsanon A, Apateerapong W, Sirivichayakul S, Siangphoe U et al (2009) Immunologic markers as predictors of tuberculosis-associated immune reconstitution inflammatory syndrome in HIV and tuberculosis coinfected persons in Thailand. AIDS Res Hum Retrovir 25:1083-1089

81. Elliott JH, Vohith K, Saramony S, Savuth C, Dara C, Sarim C et al (2009) Immunopathogenesis and diagnosis of tuberculosis and tuberculosis-associated immune reconstitution inflammatory syndrome during early antiretroviral therapy. J Infect Dis 200:17361745

82. Antonelli LR, Mahnke Y, Hodge JN, Porter BO, Barber DL, DerSimonian R et al (2010) Elevated frequencies of highly activated CD4+ T cells in HIV+ patients developing immune reconstitution inflammatory syndrome. Blood 116:3818-3827

83. Chakrabarti LA, Boucherie C, Bugault F, Cumont MC, Roussillon C, Breton G et al (2014) Biomarkers of CD4+ T-cell activation as risk factors for tuberculosis-associated immune reconstitution inflammatory syndrome. Aids 28:1593-1602

84. Mahnke YD, Greenwald JH, DerSimonian R, Roby G, Antonelli LR, Sher A et al (2012) Selective expansion of polyfunctional pathogen-specific CD4(+) T cells in HIV-1-infected patients with immune reconstitution inflammatory syndrome. Blood 119:31053112

85. Sakaguchi S (2005) Naturally arising Foxp3-expressing CD25+ CD4+ regulatory $\mathrm{T}$ cells in immunological tolerance to self and non-self. Nat Immunol 6:345-352

86. Scott-Browne JP, Shafiani S, Tucker-Heard G, Ishida-Tsubota K, Fontenot JD, Rudensky AY et al (2007) Expansion and function of Foxp3-expressing T regulatory cells during tuberculosis. J Exp Med 204:2159-2169
87. Guyot-Revol V, Innes JA, Hackforth S, Hinks T, Lalvani A (2006) Regulatory $\mathrm{T}$ cells are expanded in blood and disease sites in patients with tuberculosis. Am J Respir Crit Care Med 173:803810

88. Seddiki N, Sasson SC, Santner-Nanan B, Munier M, van Bockel D, Ip S et al (2009) Proliferation of weakly suppressive regulatory CD4+ T cells is associated with over-active CD4+ T-cell responses in HIV-positive patients with mycobacterial immune restoration disease. Eur J Immunol 39:391-403

89. Tan DB, Yong YK, Tan HY, Kamarulzaman A, Tan LH, Lim A et al (2008) Immunological profiles of immune restoration disease presenting as mycobacterial lymphadenitis and cryptococcal meningitis. HIV Med 9:307-316

90. Matsuda JL, Mallevaey T, Scott-Browne J, Gapin L (2008) CD1drestricted iNKT cells, the 'Swiss-Army knife' of the immune system. Curr Opin Immunol 20:358-368

91. Rojas RE, Chervenak KA, Thomas J, Morrow J, Nshuti L, Zalwango S et al (2005) Vdelta2+ gammadelta T cell function in Mycobacterium tuberculosis- and HIV-1-positive patients in the United States and Uganda: application of a whole-blood assay. J Infect Dis 192:1806-1814

92. Shen Y, Zhou D, Qiu L, Lai X, Simon M, Shen L et al (2002) Adaptive immune response of Vgamma2Vdelta2 $+\mathrm{T}$ cells during mycobacterial infections. Science 295:2255-2258

93. Kabelitz D, Bender A, Schondelmaier S, Schoel B, Kaufmann SH (1990) A large fraction of human peripheral blood gamma/delta + T cells is activated by Mycobacterium tuberculosis but not by its 65-kD heat shock protein. J Exp Med 171:667-679

94. Gioia C, Agrati C, Casetti R, Cairo C, Borsellino G, Battistini L et al (2002) Lack of CD27-CD45RA-V gamma 9V delta 2+ T cell effectors in immunocompromised hosts and during active pulmonary tuberculosis. J Immunol 168:1484-1489

95. Bourgarit A, Carcelain G, Samri A, Parizot C, Lafaurie M, Abgrall $S$ et al (2009) Tuberculosis-associated immune restoration syndrome in HIV-1-infected patients involves tuberculin-specific CD4 Th1 cells and KIR-negative gammadelta T cells. J Immunol 183:3915-3923

96. Wilkinson KA, Walker NF, Meintjes G, Deffur A, Nicol MP, Skolimowska KH et al (2015) Cytotoxic mediators in paradoxical HIV-tuberculosis immune reconstitution inflammatory syndrome. J Immunol 194:1748-1754

97. Espinosa E, Ormsby CE, Vega-Barrientos RS, Ruiz-Cruz M, Moreno-Coutino G, Pena-Jimenez A et al (2010) Risk factors for immune reconstitution inflammatory syndrome under combination antiretroviral therapy can be aetiology-specific. Int J STD AIDS 21:573-579

98. Lim A, D'Orsogna L, Price P, French MA (2008) Imbalanced effector and regulatory cytokine responses may underlie mycobacterial immune restoration disease. AIDS Res Ther 5:9

99. Skolimowska KH, Rangaka MX, Meintjes G, Pepper DJ, Seldon $\mathrm{R}$, Matthews K et al (2012) Altered ratio of IFN-gamma/IL-10 in patients with drug resistant Mycobacterium tuberculosis and HIVTuberculosis Immune Reconstitution Inflammatory Syndrome. PLoS One 7, e46481

100. Grant PM, Komarow L, Lederman MM, Pahwa S, Zolopa AR, Andersen J et al (2012) Elevated interleukin 8 and T-helper 1 and T-helper 17 cytokine levels prior to antiretroviral therapy in participants who developed immune reconstitution inflammatory syndrome during ACTG A5164. J Infect Dis 206:1715-1723

101. Morlese JF, Orkin CM, Abbas R, Burton C, Qazi NA, Nelson MR et al (2003) Plasma IL-6 as a marker of mycobacterial immune restoration disease in HIV-1 infection. Aids 17:1411-1413

102. Worsley CM, Suchard MS, Stevens WS, Van Rie A, Murdoch DM (2010) Multi-analyte profiling of ten cytokines in South African HIV-infected patients with Immune Reconstitution Inflammatory Syndrome (IRIS). AIDS Res Ther 7:36 
103. Narendran G, Andrade BB, Porter BO, Chandrasekhar C, Venkatesan P, Menon PA et al (2013) Paradoxical tuberculosis immune reconstitution inflammatory syndrome (TB-IRIS) in HIV patients with culture confirmed pulmonary tuberculosis in India and the potential role of IL-6 in prediction. PLoS One 8, e63541

104. Barber DL, Andrade BB, McBerry C, Sereti I, Sher A (2014) Role of IL-6 in Mycobacterium avium-associated immune reconstitution inflammatory syndrome. J Immunol 192:676-682

105. Tadokera R, Wilkinson KA, Meintjes GA, Skolimowska KH, Matthews K, Seldon R et al (2013) Role of the interleukin 10 family of cytokines in patients with immune reconstitution inflammatory syndrome associated with HIV infection and tuberculosis. J Infect Dis 207:1148-1156

106. Khader SA, Gaffen SL, Kolls JK (2009) Th17 cells at the crossroads of innate and adaptive immunity against infectious diseases at the mucosa. Mucosal Immunol 2:403-411

107. Oliver BG, Elliott JH, Price P, Phillips M, Saphonn V, Vun MC et al (2010) Mediators of innate and adaptive immune responses differentially affect immune restoration disease associated with Mycobacterium tuberculosis in HIV patients beginning antiretroviral therapy. J Infect Dis 202:1728-1737

108. Tan HY, Yong YK, Andrade BB, Shankar EM, Ponnampalavanar S, Omar SF et al (2015) Plasma interleukin-18 levels are a biomarker of innate immune responses that predict and characterize tuberculosis-associated immune reconstitution inflammatory syndrome. Aids 29:421-431

109. Conesa-Botella A, Meintjes G, Coussens AK, van der Plas H, Goliath R, Schutz C et al (2012) Corticosteroid therapy, vitamin D status, and inflammatory cytokine profile in the HIVtuberculosis immune reconstitution inflammatory syndrome. Clin Infect Dis 55:1004-1011

110. Marais S, Wilkinson KA, Lesosky M, Coussens AK, Deffur A, Pepper DJ et al (2014) Neutrophil-associated central nervous system inflammation in tuberculous meningitis immune reconstitution inflammatory syndrome. Clin Infect Dis 59:1638-1647

111. Gueders MM, Foidart JM, Noel A, Cataldo DD (2006) Matrix metalloproteinases (MMPs) and tissue inhibitors of MMPs in the respiratory tract: potential implications in asthma and other lung diseases. Eur J Pharmacol 533:133-144

112. Park KJ, Hwang SC, Sheen SS, Oh YJ, Han JH, Lee KB (2005) Expression of matrix metalloproteinase-9 in pleural effusions of tuberculosis and lung cancer. Respir Int Rev Thoracic Dis 72:166-175

113. Elkington P, Shiomi T, Breen R, Nuttall RK, Ugarte-Gil CA, Walker $\mathrm{NF}$ et al (2011) MMP-1 drives immunopathology in human tuberculosis and transgenic mice. J Clin Invest 121:1827-1833

114. Tadokera R, Meintjes GA, Wilkinson KA, Skolimowska KH, Walker N, Friedland JS et al (2014) Matrix metalloproteinases and tissue damage in HIV-tuberculosis immune reconstitution inflammatory syndrome. Eur J Immunol 44:127-136

115. Martineau AR, Nhamoyebonde S, Oni T, Rangaka MX, Marais S, Bangani N et al (2011) Reciprocal seasonal variation in vitamin D status and tuberculosis notifications in Cape Town, South Africa. Proc Natl Acad Sci U S A 108:19013-19017

116. Coussens A, Timms PM, Boucher BJ, Venton TR, Ashcroft AT, Skolimowska KH et al (2009) 1alpha,25-dihydroxyvitamin D3 inhibits matrix metalloproteinases induced by Mycobacterium tuberculosis infection. Immunology 127:539-548

117. Coussens AK, Wilkinson RJ, Hanifa Y, Nikolayevskyy V, Elkington PT, Islam K et al (2012) Vitamin D accelerates resolution of inflammatory responses during tuberculosis treatment. Proc Natl Acad Sci U S A 109:15449-15454

118. Price P, Haddow LJ, Affandi J, Agarwal U, Easterbrook PJ, Elliott $\mathrm{J}$ et al (2012) Short communication: plasma levels of vitamin D in HIV patients initiating antiretroviral therapy do not predict immune restoration disease associated with Mycobacterium tuberculosis. AIDS Res Hum Retrovir 28:1216-1219

119. Price P, Morahan G, Huang D, Stone E, Cheong KY, Castley A et al (2002) Polymorphisms in cytokine genes define subpopulations of HIV-1 patients who experienced immune restoration diseases. Aids 16:2043-2047

120. Affandi JS, Kumar M, Agarwal U, Singh S, Price P (2013) The search for a genetic factor associating with immune restoration disease in HIV patients co-infected with Mycobacterium tuberculosis. Dis Markers 34:445-449

121. Simonney N, Dewulf G, Herrmann JL, Gutierrez MC, Vicaut E, Boutron C et al (2008) Anti-PGL-Tb1 responses as an indicator of the immune restoration syndrome in HIV-TB patients. Tuberculosis 88:453-461

122. Sumatoh HR, Oliver BG, Kumar M, Elliott JH, Vonthanak S, Vun MC et al (2011) Mycobacterial antibody levels and immune restoration disease in HIV patients treated in South East Asia. Biomark Med 5:847-853

123. Phuah JY, Mattila JT, Lin PL, Flynn JL (2012) Activated B cells in the granulomas of nonhuman primates infected with Mycobacterium tuberculosis. Am J Pathol 181:508-514

124. Maertzdorf J, Repsilber D, Parida SK, Stanley K, Roberts T, Black $G$ et al (2011) Human gene expression profiles of susceptibility and resistance in tuberculosis. Genes Immun 12:15-22

125. Lai RP, Meintjes G, Wilkinson KA, Graham CM, Marais S, van der Plas H et al (2015) HIV-tuberculosis-associated immune reconstitution inflammatory syndrome is characterized by toll-likereceptor and inflammasome signaling. Nat Commun 6:8451

126. Van den Bergh R, Vanham G, Raes G, De Baetselier P, Colebunders R (2006) Mycobacterium-associated immune reconstitution disease: macrophages running wild? Lancet Infect Dis 6: 2-3, author reply $\mathbf{4}-\mathbf{5}$

127. Cicala C, Arthos J, Martinelli E, Censoplano N, Cruz CC, Chung E et al (2006) R5 and X4 HIV envelopes induce distinct gene expression profiles in primary peripheral blood mononuclear cells. Proc Natl Acad Sci U S A 103:3746-3751

128. Dudhane A, Conti B, Orlikowsky T, Wang ZQ, Mangla N, Gupta A et al (1996) Monocytes in HIV type 1-infected individuals lose expression of costimulatory B7 molecules and acquire cytotoxic activity. AIDS Res Hum Retrovir 12:885-892

129. Pulliam L, Sun B, Rempel H (2004) Invasive chronic inflammatory monocyte phenotype in subjects with high HIV-1 viral load. J Neuroimmunol 157:93-98

130. Lawn SD, Wainwright H, Orrell C (2009) Fatal unmasking tuberculosis immune reconstitution disease with bronchiolitis obliterans organizing pneumonia: the role of macrophages. Aids 23:143-145

131. Tran HT, Van den Bergh R, Loembe MM, Worodria W, MayanjaKizza H, Colebunders R et al (2013) Modulation of the complement system in monocytes contributes to tuberculosis-associated immune reconstitution inflammatory syndrome. Aids 27:1725-1734

132. Tran HT, Van den Bergh R, Vu TN, Laukens K, Worodria W, Loembe MM et al (2014) The role of monocytes in the development of tuberculosis-associated immune reconstitution inflammatory syndrome. Immunobiology 219:37-44

133. Dunkelberger JR, Song WC (2010) Complement and its role in innate and adaptive immune responses. Cell Res 20:34-50

134. Andrade BB, Singh A, Narendran G, Schechter ME, Nayak K, Subramanian S et al (2014) Mycobacterial antigen driven activation of CD14++CD16- monocytes is a predictor of tuberculosisassociated immune reconstitution inflammatory syndrome. PLoS Pathog 10, e1004433

135. Roy S, Barnes PF, Garg A, Wu S, Cosman D, Vankayalapati R (2008) NK cells lyse T regulatory cells that expand in response to an intracellular pathogen. J Immunol 180:1729-1736

136. Vankayalapati R, Wizel B, Weis SE, Safi H, Lakey DL, Mandelboim O et al (2002) The NKp46 receptor contributes to 
NK cell lysis of mononuclear phagocytes infected with an intracellular bacterium. J Immunol 168:3451-3457

137. Vankayalapati R, Klucar P, Wizel B, Weis SE, Samten B, Safi H et al (2004) NK cells regulate CD8+ T cell effector function in response to an intracellular pathogen. J Immunol 172:130-137

138. Conradie F, Foulkes AS, Ive P, Yin X, Roussos K, Glencross DK et al (2011) Natural killer cell activation distinguishes Mycobacterium tuberculosis-mediated immune reconstitution syndrome from chronic HIV and HIV/MTB coinfection. J Acquir Immune Defic Syndr 58:309-318

139. Pean P, Nerrienet E, Madec Y, Borand L, Laureillard D, Fernandez M et al (2012) Natural killer cell degranulation capacity predicts early onset of the immune reconstitution inflammatory syndrome (IRIS) in HIV-infected patients with tuberculosis. Blood 119:3315-3320

140. Chackerian A, Alt J, Perera V, Behar SM (2002) Activation of NKT cells protects mice from tuberculosis. Infect Immun 70: 6302-6309

141. Berry MP, Graham CM, McNab FW, Xu Z, Bloch SA, Oni T et al (2010) An interferon-inducible neutrophil-driven blood transcriptional signature in human tuberculosis. Nature 466:973-977

142. Dorhoi A, Yeremeev V, Nouailles G, Weiner J 3rd, Jorg S, Heinemann E et al (2014) Type I IFN signaling triggers immunopathology in tuberculosis-susceptible mice by modulating lung phagocyte dynamics. Eur J Immunol 44:2380-2393

143. Abel B, Thieblemont N, Quesniaux VJ, Brown N, Mpagi J, Miyake K et al (2002) Toll-like receptor 4 expression is required to control chronic Mycobacterium tuberculosis infection in mice. $\mathrm{J}$ Immunol 169:3155-3162

144. Reiling N, Holscher C, Fehrenbach A, Kroger S, Kirschning CJ, Goyert $\mathrm{S}$ et al (2002) Cutting edge: Toll-like receptor (TLR)2- and TLR4-mediated pathogen recognition in resistance to airborne infection with Mycobacterium tuberculosis. J Immunol 169:34803484

145. Tan DB, Lim A, Yong YK, Ponnampalavanar S, Omar S, Kamarulzaman A et al (2011) TLR2-induced cytokine responses may characterize HIV-infected patients experiencing mycobacterial immune restoration disease. Aids 25: $1455-1460$

146. Barber DL, Mayer-Barber KD, Antonelli LR, Wilson MS, White S, Caspar P et al (2010) Th1-driven immune reconstitution disease in Mycobacterium avium-infected mice. Blood 116:3485-3493

147. Hatziioannou T, Evans DT (2012) Animal models for HIV/AIDS research. Nat Rev Microbiol 10:852-867 